\title{
Astonishment and joy: Luke 1 as told from the perspective of Elizabeth
}

\begin{abstract}
Author:
Robin Gallaher Branch ${ }^{1,2}$

\section{Affiliations:}

${ }^{1}$ Faculty of Theology, North-

West University, South Africa

${ }^{2}$ Department of Bible and

Theology, Victory University,

Memphis, United States
\end{abstract}

\section{Correspondence to:}

Robin Gallaher Branch

Email:

rgbranch@victory.edu

\section{Postal address:}

Victory University; 255

North Highland, Memphis,

TN 38111; USA;

901-320-9700 x 1091

Dates:

Received: 25 Apr. 2012

Accepted: 11 Aug. 2012

Published: 25 July 2013

How to cite this article:

Branch, R.G., 2013,

'Astonishment and joy:

Luke 1 as told from the perspective of Elizabeth', In die Skriflig/In Luce Verbi 47(1), Art. \#77, 10 pages. http://dx.doi.org/10.4102/ ids.v47i1.77

\section{Copyright:}

(C) 2013. The Authors.

Licensee: AOSIS

OpenJournals. This work

is licensed under the

Creative Commons

Attribution License.
Read online:
This article, a dramatic, scholarly monologue, examines the events that Luke 1 recounts, retelling them from the viewpoint of Elizabeth, the elderly wife of Zechariah, a priest. It uses a literary method and presents the monologue as an eyewitness account. ${ }^{1}$ Luke 1 frames its central events from a female and gynocentric perspective. ${ }^{2}$ As a participant in the infancy narrative in Luke 1 , Elizabeth should figure predominantly in scholarly articles and sermons. Surprisingly, she does not. Instead, scholarly, lectionary and congregational attention focuses primarily on Zechariah and Mary, two of the other speaking characters. Consequently, this article seeks to showcase, honour, and analyse Elizabeth, an overlooked yet pivotal character in Luke's gospel. Via a dramatic monologue, it lets her speak about the astonishing recent events in her life and thereby invites readers and hearers to share her joy, surely a singular theme in Luke's gospel.

Verwondering en blydskap: Lukas 1 hervertel vanuit die perspektief van Elisabet. Hierdie artikel, 'n wetenskaplike monoloog in dramavorm, ondersoek die gebeure volgens Lukas 1 . Dit word hervertel vanuit die perspektief van Elisabet, die bejaarde vrou van die priester Sagaria. 'n Literêre metode word gebruik en die monoloog word as 'n ooggetuieverslag aangebied. Lukas 1 se hoofgebeure word vanuit ' $n$ vroulike perspektief asook dié van ongebore babas ('gynocentric') gekontekstualiseer. As inherent deel van die jeugvertelling van Lukas 1 behoort Elisabet oorwegend in wetenskaplike artikels en preke te figureer. Dit is verrassend dat dit nie gebeur nie. In wetenskaplike leesstukke en tydens gemeentelike byeenkomste word hoofsaaklik op Sagaria en Maria, die ander twee hoofkarakters, gefokus. Elisabet is 'n miskende sleutelkarakter in die Evangelie van Lukas en daarom poog hierdie artikel om Elisabet uit te lig, eervol te erken en te analiseer. Deur dramatiese monoloog kry Elisabet die geleentheid om oor die verstommende gebeure van haar onlangse lewe te praat. Sy nooi hiermee die lesers en toehoorders uit om in haar vreugde te deel - sekerlik 'n buitengewone tema in die Lukasevangelie.

\section{Setting and preliminary instructions}

The Announcer and six other people come on stage. They form a line and all have scripts.

Announcer: 'Good morning. You are about to see and hear a dramatic monologue based on Luke $1 .{ }^{3} \mathrm{We}$ will first read the chapter as it is rendered in the NIV, the New International Version.'

The Announcer begins with Luke 1:1-5.

The other six follow with these passages: Luke $1: 5-25 ; 26-38$; 39-45; 46-46; 57-66; and 67-80. When the six have finished, they leave the stage. The Announcer remains on stage.

Announcer: 'As you just heard, the chapter's key characters are Zechariah a priest; Gabriel, an angel; Elizabeth, the wife of Zechariah; Mary, the kinswoman of Elizabeth; and John, the infant son of Zechariah and Elizabeth. ${ }^{4}$

1.This is my third published drama. The first was 'Teaching the Old Testament Book of Proverbs Via a Play' (Branch 2005:57-69). The Society of Biblical Literature Forum http://www.sbl-site.org/Article. aspx?Articleld $=488$ also published it online. The second was ' $\mathrm{He}$ is Risen! A Play Based on Acts 1:1-12' (Branch 2012:229-258).

2.Bauckham (2002:47) calls Luke 1:5-80 'a gynocentric text'. The infancy narrative in Luke sets the stage for everything else that follows in the gospel (Murphy 2005:197). Bauckham (ibid:51), writing about the interaction of Mary and Elizabeth, says that it 'is undoubtedly as the mothers of their unborn sons that they are of central importance in Luke's narrative, but it is from their female perspectives that we view the central events of the narrative' (Bauckham's italics). However, Bauckham, in his chapter on Elizabeth and Mary (Bauckham ibid:47-76), gives scant analysis to Elizabeth and concentrates solely on Mary.

3.Like the first chapter of 1 Samuel, Luke 1 contains the perspective of women. 'Astonishment and joy: Luke 1 as told from the perspective of Elizabeth' is creative, religious drama. Creative religious drama can become an effective tool 'that just might open the door to new interest in the 'an imp in the geat bibical the 'an improvisational, nonexhibitional, process-centered form of drama in which participants are guided by a leader to imagine, enact, and reflect upon human experience, (Barragar ibid:16, quoting from 'Redefining Creative Dramatics. A CTAA Project, 1977, a paper from the Redefinitions Committee of the Children's Theatre Association of America.) Lostracco \& Wilkerson (2008:iii-vi) note that the main elements of a story are the central idea, character, conflict, point of view, setting, language and tone.

4.Elizabeth and Mary are the principal persons in Luke 1. Although the chapter begins and ends with Zechariah, he is mute because of a loss of speech in its middle portions. This gives his wife, Elizabeth, a chance to occupy centre stage (Martin 1982:394). 
'We have been invited today to the home of Elizabeth and Zechariah. ${ }^{5}$ It is in the hill country of Judea. Imagine ${ }^{6}$ with me their simple stone house in a small village. ${ }^{7}$ It has a couple of wooden tables and chairs. [The Announcer gestures stage left and stage right.] The view from a window looks out on a pasture where sheep graze. ${ }^{8}$ [The Announcer gestures toward the audience.]

'The time is around $4 \mathrm{BC}$. Herod is king in Judea. The hated Romans occupy the land. ${ }^{9}$

'A great event has just taken place in their small village. Elizabeth will tell you about it. ${ }^{10}$ [The Announcer exits.]

Elizabeth enters from upstage left ${ }^{11}$. A separate room where John sleeps is stage left. She wears a new shawl. ${ }^{12}$ She is about 68 years old and yet lovely and energetic. She bustles. She is full of joy. She has an expressive, mobile face.

\section{Introduction}

[Elizabeth enters smiling. She has fully recovered from the birth of her son. She greets the members of the audience warmly, confidently.] Hello. I'm Elizabeth. ${ }^{13}$ My baby son, John, is asleep. He was

5.This monologue is a religious drama. Drama, in general, may persuade or provoke even whilst it entertains. Drama may portray a slice of life in a timeframe. It also 'offers provocative ideas about the life it portrays, and it provides an imaginative extension of its possibilities' (DiYanni 2008:901). Religious drama often investigates these elements (Edyvean 1970:17):

1. Humankind's human condition.

2. Humankind's spiritual condition.

3. The God-man relationship.

4. The meaning of an experience that a person undergoes.

5. The limits of a human being's power.

6. The feelings that a person experiences.

7. A person's self-examination.

6.Imagination is a marvellous teaching tool and is useful for training adults and children in the faith (see Stonehouse 1998:158). Loader (2007:ix-x) draws on imagination, principal component of all drama including this monologue, in his short book that highlights the lives (and writings) of significant characters in the New Testament: Jesus, Paul and John. Throughout the book, he engages senses like smell and sound and brings up economic factors like unemployment, slavery and the fragility of life. and brings up economic factors like unemployment, slavery and the fragility of life. He reminds readers of the importance of the seasons and the disparity between the rich and poor as well as the different perspectives of youth and age. Loader (2007: $x$ ) imagine our way into' their context. 7.The setting is where the events of the drama occur (Lostracco \& Wilkerson 2008:31).
What I like particularly about Loader's work is how he uses sources, facts and scholarly work and manages to invite us back into the biblical world as participants.

8.This short description, sketched in a few words with a language paintbrush, creates a mental image, a sensory impression, in the minds of readers and hearers (Lostracco \& Wilkerson 2008:37)

9.Zechariah, Elizabeth and their son John link the Old Testament period to God's new work in New Testament times. It seems that God's silence has lasted some 400 years. At least there has been no further revelation of a prophet or an angel until Gabrie comes to Zechariah in the Temple (see Geldenhuys 1979:60). Anna, however, is a named prophetess (Lk 2:36-38)

10.Luke's narrative holds a three-fold power, according to Kuist (1948:289): 'The power to attract and to hold the reverent attention of young and old; the power to communicate such significant creative impulses to Christian art and music; (and) the power to sustain and to out-live such acute and protracted historical criticism

11.Elizabeth is the monologue's major character. She is crucial to the re-telling of Luke 1. Furthermore, the story revolves around what she says and does (Lostracco \& Wilkerson 2008:13). She is a dynamic character, rather than a flat one, because she grows and changes during the story, she expresses many emotions and the audience gets to know her (see Lostracco \& Wilkerson ibid:15).

12.Elizabeth wears rustic clothes - probably a loose dress or long skirt, an over blouse and cloth belt. She has sandals. She lovingly touches her new shawl throughout the monologue. She is beautiful, although elderly and wrinkled.

13. Luke 1 gives textual importance to women. Martin (1982:395) notes the 'feminine character of the symbols' in the chapter and acknowledges 'the almost universal neglect of these feminine symbols by Protestant male interpreters'. An impetus in my research into the character of Elizabeth and in writing this monologue about her is that I have never heard a sermon on her life. Therefore, I try, in this monologue, to is that I have never heard a sermon on her life. Therefore, I try, in this monologue, to (see Lostracco \& Wilkerson 2008:9). I like her very much. I also respect and admire her. I understand her longing for a child and her joy in giving her husband a son. To her. I understand her longing for a child and her joy in giving her husband a son. To
me, Luke 1 presents her with much kindness and sensitivity as someone whom God me, Luke 1 presents her with much kindness and sensitivity as someone whom God
has used prominently - and as someone delightfully amazed about this use! born last week and circumcised today. Zechariah, my husband, is in town talking, talking, talking. Mary, my kinswoman, left two weeks ago. The house is deserted, and I have a chance to tell you a bit about what has happened in our lives. ${ }^{14} \mathrm{I}^{\prime} \mathrm{ll}$ start with who we are, our background..$^{15}$ Then I'll tell you about Zechariah's experience in the Temple nine months ago. I'll talk about our marriage - over the years and now. Mary visited us; you surely want to know about her. And then I'll come around to what happened today at the circumcision. ${ }^{16}$ It has all been so unexpected. ${ }^{17} \mathrm{I}$ am astonished at the work of the Holy One of Israel. I am full of joy because I and my family figure in his ongoing plan. ${ }^{18} \mathrm{Oh}$, and this is my new shawl. ${ }^{19}$ Zechariah gave it to me today. ${ }^{20}$ [She touches her shawl to her cheek and smiles; it is a loving gesture.]

\section{Our background}

[Elizabeth walks and smiles.] I married at age 13. That was 55 years ago. I married a member of my tribe, the tribe of Levi. ${ }^{21}$ [Proudly.] I am a descendant of Aaron, the brother of Moses. ${ }^{22}$ I married Zechariah, who belongs to the priestly division of Abijah. ${ }^{23}$ He was 17 and handsome. [She smiles fondly.]

[Elizabeth addresses the guests to her house and gestures.] We live in the hill country of Judea in a village about five miles west of Jerusalem. ${ }^{24}$ We are people of integrity and some

14.The narrative is in the first person in this monologue. Elizabeth uses pronouns like $I$ and $m e$. In literary language, this is a first person point of view (Lostracco \& Wilkerson 2008:25).

15.The group of people in the birth stories of John and Jesus - Zechariah, Elizabeth, Mary, Joseph, Anna, Simeon and the Magi - exhibit the character traits of righteousness and faith. They are practical people of prayer - and prayer involves intercession, listening, long waits, discerning God's voice and action. They are not powerful or famous people and, with the exception of the Magi, are not wealthy (Dean 1983:22) Elizabeth's monologue details a sequence of events. This sequence is the plot of the drama (Lostracco \& Wilkerson 2008:19).

16.Karris (1985:352) maintains that Luke's soteriology, as the infancy narratives of John and Jesus express it, differs from that of other New Testament writers who emphasise expiation and the transcendence of God. For example, in Paul's soteriology, a transcendent God cleanses away sin via the blood of Jesus (Rm 3.24-25). Luke, in transcendent God cleanses away sin via the blood of Jesus (Rm 3:24-25). Luke, in contrast, presents a God who is present during life - from birth, through sin and then in death. This 'with-ness,' Karris (ibid:352) argues, is designed to appeal to
Theophilus and subsequent readers. It shows that God meets us on a deep level and Theophilus and subse
saves us in Jesus.

17.See Wright 2004:7.

18.Scholars, amongst them William Barclay (1956:8), note the prevalence of joy in Luke 1. Barclay (1956:9) adds that great joy is proportional to a great task.

19. Luke does not mention that Zechariah gives Elizabeth a shawl. I inserted it for several reasons. Firstly, it gives Elizabeth a prop that helps the audience imagine her character. Secondly, husbands throughout history have given their wives presents at the births of children. My imaginative elaboration, by including a shawl, follows the Jewish tradition of Midrash. Midrash is creative exegesis, because it combines wordplay, storytelling skill and interpretation. These elements, when they come together, 'liberate pleasure, creativity, and knowledge' (Marx 2000:16).

20.Luke 1 brims with human elements: the longing for a child, doubt, joy, faith, unbelief, friendship, praise and danger. It combines the human and the divine and does not present them as an oxymoron. Instead, the text accepts the miraculous. It presents the idea that the humanity of Jesus saves humanity and does not rescue it from being human (see Hann 1986:297).

21.The biblical text emphasises that the baby, John, to come from this union is of priestly stock and in the great heritage of Israel's prophets (see Fitzmyer 1981:317).

22.Significantly, Elisheba (Elizabeth) was the name of Aaron's wife (Ex 6:23) (Nolland 1989:26). To be a priest's daughter and married to a priest was a double distinction. Geldenhuys gives a colloquial expression that describes an excellent woman: she deserves to be married to a priest (Geldenhuys 1979:62). Zechariah and Elizabeth represent the best of Israel. They show that there was true piety, based not on meticulous legalism but on practiced prayer, in Israel (Dean 1983:20).

23.See Luke 1:5-6. The division of Abijah is the eighth (Morris 1988:75).

24.According to tradition, Elizabeth and Zechariah lived in Ein Karem, about five miles west of Jerusalem and 80 miles from Nazareth (Holy Apostles Convent 1989:119). 
education. ${ }^{25}$ We both can read and write. This is very important. Zechariah as a priest reads the scrolls and studies them. ${ }^{26} \mathrm{We}$ determined immediately in our marriage to walk uprightly in the sight of God and each other. We decided to observe all the Lord's commands and regulations. We have tried with all our heart to please him. ${ }^{27}$

I guess any marriage has its hurting point, its tender or sensitive issues. Ours was my barrenness. ${ }^{28}$ We prayed. I fasted. We sought the Lord. Month after month. Year after weary year. No child. Here in Israel, childlessness is considered a curse. ${ }^{29}$ I was blamed..$^{30}$ My neighbours talked about me first behind my back and then to my face. Over the years, my friendships dwindled. ${ }^{31}$ [This is obviously very hard to say. Elizabeth cries; the hurt is raw and real.]

[Elizabeth is very concerned; her mobile face expresses much sorrow.] I was afraid Zechariah would divorce me. You probably know the story of Hannah. She longed for a child and her husband Elkanah took a second wife in order to have children. Peninnah had many children and made Hannah's life miserable. ${ }^{32}$ The Lord heard Hannah's prayer and she gave birth to Samuel. Zechariah never divorced me, and for that I am so grateful. Instead he chose to share my shame. But we could not meet each other's eyes; for years there was silence between us. ${ }^{33}$ [She hangs her head.]

\section{Zechariah}

[Elizabeth seems to shake herself. She smiles and touches the shawl with tenderness.] Now I will tell you a bit about Zechariah. ${ }^{34} \mathrm{I}$

25.The biblical text emphasises the couple's integrity, faith and advanced age. The uprightness of Zechariah, Elizabeth and Mary shines rather than do any trappings of wealth, fame or power (see Dean 1983:22). Green (1997:61) observes that the description of Zechariah and Elizabeth introduces the readers to the world of 'first-century Palestinian Jewish piety' because of its 'references to prayer, worship, fasting, and expectant waiting'.

26.Bauckham (2002:71) thinks that Zechariah and Elizabeth did not have high status, but were amongst the many priests who lived amongst the peasant population. He (Bauckham ibid:71) argues that Luke 1:36 points dubiously to Mary's connection to the priesthood, especially since priestly descent came through the male line.

27.Zechariah and Elizabeth represent the best of Israel. They show that there was true piety, based not on meticulous legalism but on practiced prayer, in Israel (Dean 1983:20) - see Luke 1:5-6. Nonetheless, the couple's barrenness seems to indicate that 'God seemed to have neglected their dogged fidelity to him' (Wansbrough that 'God seemed to have neglected their dogged fidelity to him' (Wansbrough
2007:17) - at least at first glance. Because of their advanced ages, no doubt their neighbours and society treated them as "has-beens", ready to sink into decrepitude and oblivion' (Wansbrough 2007:19).

28.Conflict, in this dramatic monologue, 'results from a cause and effect relationship between events' (Lostracco \& Wilkerson 2008:19).

29.See Harpers Bible Dictionary 1985:161 and Genesis 20:18.

30.Barrenness is the essential social fact about Elizabeth and her great, ongoing disgrace (Bauckham 2002:72). Barrenness is an Old Testament pattern in the stories of Sara or Sarah, Rachel, Hannah and the wife of Manoa (see Gn 18:10-15; Gn 30:102 Jdg 13:1-5).

31.Ryken suggests a number of reasons for suffering. Sometimes suffering is for the sake of righteousness. Sometimes sin causes suffering. Sometimes suffering results from the sins of others. 'And sometimes God allows us to suffer because he wants to be glorified through our suffering' (Ryken 2009:18). The biblical text indicates that the suffering of this couple, Zechariah and Elizabeth, leads to a miracle that glorifies God.

32.See 1 Samuel 1. Elizabeth's story also resembles that of Sarah who longed for a child and conceived when she was 89 or 90, well past childbearing age (Gen 18:1-15).

33.Morris (1988:75) writes that 'their childless state (was) hard for them to understand for people believed that God would bless faithful servants by giving them children'

34.The text presents Zechariah 'as an Abraham-like figure' (Brown 1988a:483). call him an old coot! ${ }^{35}$ And he is! He has a bristly white beard. He has to have the last word! He is always right! Over the years he became more and more precise.

[She pauses and cocks her head.] Well, those are the ways he was. Zechariah, my husband, is much different now. But I get ahead of myself. I've studied my husband for years and tried to please him. He wants his meals on time, and his priestly garments laundered just so. On the one hand, he is scholar and a man of prayer. He loves the Lord, the Holy One of Israel. He believes the prophets; he sings the psalms. Yet, on the other hand he is a man of facts. The facts. The facts. He believes facts. Well, in these last nine months, he recognises that miracles are facts. [Elizabeth expresses wonderment; her face lights up.] Zechariah's changed. But I'll get to that.

\section{The time in the Temple}

[Elizabeth continues. She smiles and expresses excitement.] Now I'll tell you when our lives started to change. ${ }^{36}$ Temple assignments are drawn by lots. Zechariah is of the order of Abijah, one of the 24 shifts in the management of the Temple; each had a shift of a week twice a year. ${ }^{37}$ We went to Jerusalem together. Zechariah loved his service. He loved praying for Israel. His temperament was such that he took his job very seriously. ${ }^{38}$ This was the honour of a lifetime; Zechariah was very excited.

He was chosen by lot to administer incense outside the Holy of Holies. ${ }^{39}$ I waited outside with many other worshippers. As the officiating priest, Zechariah's job was to clean the altar of incense and to offer fresh incense. ${ }^{40}$

35.In an earlier exegesis of Zechariah's encounter with Gabriel, I wrote that 'Zechariah's prophecy exudes joy. This is amazing, because Luke introduces Zechariah as something of an old grump' (Branch 2009.35). In this monologue, I imagine what something of an old grump' (Branch 2009:35). In this monologue, I imagine what because he changes from the time of his encounter with Gabriel to the time of his prophetic song.

36.The encounters in Luke 1 smack of realism and theological insights. Theology technically the study of God - expands with the stories in Luke 1. Steuernage (2003:103) points out that theology begins with unexpected encounters, encounters set in the messy confines of day-to-day lives - see Luke 1:8-9. Notice that in recounting Luke 1:5-25, I pause frequently. Pausing avoids the tendency when reading and reciting to race through a text. I hear Gabriel's encounters first with Zechariah and then with Mary as lasting longer than the 45 seconds or fewer it takes to read each aloud. We know the biblical text in both testaments for its brevity A dramatic monologue presents human reactions that are normal, possible and/or implied in the text. Human reactions take time.

37.See Nolland (1989:27). Geldenhuys (1979:62-63) gives several insights into priests and their duties. Evidently, at the time of Zechariah, there were thousands of priests and a priest could not burn incense more than once in his lifetime. Priests offered incense twice a day, in the morning and then again at $3 \mathrm{pm}$. As an officiating priest Zechariah could enter the holy place, the space inside the Temple and just in front of the Holy of Holies. The high priest alone could enter the Holy of Holies once a year only, on the Great Day of Atonement. Barclay (1956:3-4) also outlines Zechariah's priestly duties. Every morning and evening, he made a sacrifice for the nation of Israel. The sacrifice involved a burnt offering of a year-old male lamb without spot or blemish. Before he made the sacrifice, he offered incense, enabling the sacrifices to ascend to God as a sweet-smelling savour.

38. Nevertheless, Zechariah also listened in prayer and in doing his duty. He gave himself the chance to hear God's voice. Barclay (1956:5) notes that God's voice comes to those who listen for it, as did Zechariah.

39.It was the apex of Zechariah's career. Once a priest was chosen for Temple service, he was not eligible to serve again (Ryken 2009:20). Fitzmyer (1981:317-318) gives the afternoon as the time. A priest could serve throughout his life without serving in the Temple. However, if the lot fell to him, it was the highlight of his life. Zechariah certainly 'was thrilled to the core of his being,' Barclay (1956:4) writes. Green (1997:69) says that God chose Zechariah singularly for this special and blessed honour.

40.Fitzmyer (1981:323-324) says that priests offered incense at the table of incense. The table was 'in the holy place' before the curtain separating the holy place from the most holy place (Ex 30:1-6; Nolland 1989:27-28). 
[Throughout this section, Elizabeth acts out Zechariah's encounter and emotions.] Well, Zechariah was meticulously performing his duties when an angel of the Lord appeared to him standing at the right side of the altar of incense. ${ }^{41}$ Zechariah was startled and then afraid. ${ }^{42} \mathrm{He}$ wrote me this later, because he has been unable to speak. But again I get ahead of myself. What I am telling you is what he wrote down for me when we came home.

The angel then said to him, 'Do not be afraid, ${ }^{43}$ Zechariah; your prayer has been heard. ${ }^{\prime 4}$

Zechariah wondered what prayer. ${ }^{45}$ Then the angel was specific. 'Your wife Elizabeth will bear you a son, and you are to give him the name John. ${ }^{\prime 46}$

Zechariah gasped. The angel continued. 'He will be a joy and delight to you, and many will rejoice because of his birth. ${ }^{\prime 47}$

Zechariah gasped again. The angel kept on. 'He will be great in the sight of the Lord. ${ }^{\prime 4}$

Then the angel gave some requirements about how to raise this boy, John. The angel said that 'he is never to take wine or other fermented drink' ${ }^{49}$

Zechariah's mouth was open and his eyes were big! ${ }^{50}$ I think the angel chuckled a bit. [She laughs, too.] The angel continued

41.Morris (1988:76) comments that, because people facing the east often give directions in the Bible from their standpoints, it is possible that the angel stood between the altar of incense and the golden candlestick. Angelic visitations that announced births are common throughout the Old Testament (see Gen 16:10-11, 17:15-19, 18:10-15 and 25:23 as well as Jud 13:3-21) (Bock 1994:36).

42.Zechariah is facing a crisis. A crisis is an element in drama. A play is the actualisation of a segment and a slice of life in a set time. Characters who act and speak in ways relevant to the situation - often a crisis that has captured them and which is happening to them right now (Ehrensperger 1962:23) - bring it to life (see Lk 1:11).

43.Conrad (1985:660-663) explores Old and New Testament texts containing 'fear not.' The phrase is used to comfort a dying woman in labour (Gen 35:17 and Sam 4:20). God addresses Abram with the phrase in the vision that Genesis 15:1 recorded. Gabriel uses the same words to Zechariah in Luke 1. Conrad (ibid:661) says that 'fear not' in the New Testament 'seeks to eliminate the fear aroused not only by the appearance of the numinous but also by other circumstances associated with the announcement of the birth of a son'. These normal anxietie could include the life of the mother during gestation and labour, the reputatio of the mother, the reaction of the general populace and the responsibilities of parenting a child with a divine destiny. Conrad (ibid:663) sees Gabriel's declaration to Zechariah to 'fear not' (Lk 1:13) as words of comfort similar to those of the Lord to Abram in Genesis 15:1.

44.Gabriel mentioned Elizabeth by name, suggesting that Zechariah was praying for her (Ryken 2009:21). Gabriel appeared to Daniel many centuries before (see Dan 9:20-21). Brown (1988a:485) writes, 'There can be little doubt, then, that Luke intends us to see a parallelism between Gabriel's appearance to Daniel and his appearance to Zechariah' (see Lk 1:11-17).

45.As the officiating priest representing the people of Israel, his prayers were to include prayers for Israel's spiritual redemption (Geldenhuys 1979:63)

46.The name John indicates that God will grace the child (see Fitzmyer 1981:325). His name means 'God has been gracious' and its cognate means 'prayer for favour' (Nolland 1989:29). According to Bede, 'Whenever in the Scriptures a name is imposed or changed ... by God, it is indicative of great praise and virtue' (Just 2003:9). Ambrose writes that the angel announced not greatness of body but of soul regarding John (Just 2003:9).

47.Green (1997:74) notes the escalation of the angel's remarks about John. John will be important to Zechariah, then to many and finally in the sight of the Lord. Eventually, John's importance 'can be appreciated only against the backdrop of what God has been doing, and how God is even now bringing his aim to its consummation in part through his human agent John' (Green ibid:112).

48.Bock (1994:37) says that the major message of Gabriel's visit to Zechariah and to Luke's readers 'is that God will do what he promises in his own way'.

49.The area's common strong drink was barley beer (Fitzmyer 1981:326).

50.They should be because the angel heaped accolade upon accolade and blessing upon blessing on the couple and this child (Ryken 2009:23). with this news about our son: 'He will be filled with the Holy Spirit even from his mother's womb.'

And I can tell you that that has happened! [Elizabeth says this with great joy.]

Then the angel concluded about the purpose of our son and the reaction of some people of Israel. Our son, the angel said, 'will bring back many of the people of Israel to the Lord their God.' Our son will go before the Lord, in the spirit and power of Elijah. ${ }^{51}$ Our son will turn the hearts of the fathers to their children and the disobedient to the wisdom of the righteous. Our son will make ready a people prepared for the Lord. ${ }^{52}$

The news overwhelmed Zechariah. [She pauses and paces.] He paced back and forth in front of the altar of incense. The angel waited patiently. Zechariah undoubtedly pulled his beard, which is what he does when he is thinking through something.

[Elizabeth turns stage left.] Zechariah turned to the angel and said, 'How can I be sure of this? I am an old man and my wife is well along in years. ${ }^{.53}$

[Elizabeth faces the audience.] That is not something you say to an angel! ${ }^{54}$ I could have told him that! ${ }^{55}$ Zechariah has since learned a hard lesson. ${ }^{56}$ [Elizabeth turns stage right.] The angel took umbrage ${ }^{57}$ and said this: 'I am Gabriel. I stand in the presence of God, and I have been sent to speak to you and to tell you this good news. ${ }^{58}$

[Elizabeth faces the audience.] Then the angel decreed a punishment for Zechariah! Zechariah has not been reprimanded for decades! The angel said to Zechariah, 'You will be silent and not able to speak until the day this happens because you did not believe my words, which will come true at their proper time. ${ }^{59}$

51.John will not be a reincarnation of Elijah but will be like that firebrand prophet in temperament, mannerisms and unequivocal message (see Fitzmyer 1981:321).

52.The angel's description of John's role indicated he would 'do much more than an ordinary prophet,' Geldenhuys (1979:65), rightly says (see Lk 1:16-18)

53.Zechariah, like his wife Elizabeth, is a dynamic character in this monologue. Often what characters say is more revealing than their actions (Lostracco \& Wilkerson 2008:17). Significantly, Zechariah does not believe Gabriel, God's representative that a restorative miracle could happen to him and to his wife Elizabeth in their old age (Branch 2009:35, 37).

54.Nolland (1989:33) surely understates the enormity of Zechariah's statement when he writes about 'the impropriety of Zechariah's question'.

55.Morris (1988:78) observes that Gideon and Hezekiah (Jud 6:36-39 and 2 Kgs 20:8) also asked for a sign - but Zechariah's tone and spirit were different. Speaking from unbelief, Zechariah 'reminds the angel that both he and his wife are old (his I is emphatic). Babies are not born to people like them. The angel retorts with an emphatic / of his own as he discloses his name,' Morris (ibid:78) says.

56.One view about Zechariah's response to Gabriel is that Zechariah's own faith worked against him. He did not believe that he was worthy - although Gabriel and his sender God, did - and was punished for his scepticism (Holy Apostles Convent 1989:126). Green (1997:63) comments that here in the story the tables turn on Zechariah in favour of Elizabeth. She is introduced as barren and disgraced, but becomes pregnant and is restored to a position of honour at the close of the chapter.

57.See Branch (2009:35). Wright (2004:7) expresses it as: 'We can almost see the angel putting his hands on his hips and telling Zechariah off for presuming to doubt his word.'

58.Zechariah became mute, arguably as did Daniel (Dan 10:15-17; see Brown 1988a:487). Gabriel's name means 'man of God' (Geldenhuys 1979:67) or, according to Bede, 'strength of God' (Just 2003:13).

59.Silence descends immediately upon Zechariah. He is unable to pronounce the priestly blessing as Elizabeth soon recounts (Nolland 1989:33). 
Then the angel left. Zechariah tidied up the area around the altar and came out to see us worshippers. He was very dazed. He could not speak. He looked for me. I pushed forward in the crowd and came to him. He took my hand. Another priest pronounced the blessing. ${ }^{60}$ We all knew something profound had happened in the Temple. ${ }^{61}$ [Elizabeth's face shows concern.]

We walked the distance back to our lodgings. Zechariah was alternately crying, filled with emotion, trying to talk, remorseful, and skipping! I couldn't believe what I was seeing. My husband was skipping! I fed him dinner. He went to sleep with a smile on his face.

[She picks up the pace of the story.] His duties at the Temple lasted a few more days. Everybody avoided him, because he couldn't speak. We walked home from Jerusalem and his confusion seemed to lift once we got home. He brought out a writing tablet.

[Elizabeth gets more and more excited, more and more joyful throughout this portion. Her voice gets louder and louder, too.] He wrote me the angel Gabriel's words. I rejoiced! I believed! They concerned me, too! I became the big noise in our small house. We hugged. We kissed. We prayed together. We thanked the Lord. We were secluded in our house for a second honeymoon period. Our neighbours kept their distance. They thought we were odd before - and now they thought we were really odd!

\section{[Slowly.] And I became pregnant. ${ }^{62}$ [Elizabeth is full of wonder and adoration.]}

I hid myself for five complete months and worshipped the Holy One of Israel. ${ }^{63}$ I did not tell anyone of my joy. ${ }^{64}$ No one except Zechariah knew I was pregnant. Truly, my pregnancy is a miracle, an answer to the prayers of Zechariah in the Temple and our prayers throughout our marriage. ${ }^{65}$ My shame is taken away. I am like Sarah - although I am younger than she! and enjoying my husband again and bouncing a baby boy on my knee. Truly with God nothing is impossible! ${ }^{66}$

60. It was customary for an officiating priest to bless the worshippers. Zechariah, because of his muteness, could not pronounce the blessing (see Fitzmyer 1981:320).

61. Ryken (2009:25) rightly sees the humour in the situation. He (2009:26) comments: 'Poor Zechariah! He had just heard the greatest news that anyone had heard in about four centuries, but he wasn't able to tell anyone about it. All he could do was make hand signals. But just imagine trying to play charades with Gabriel's prophecy!'

62. Luke tells the story of two miraculous births: 'Zechariah and Elizabeth, in their old age and despite their barrenness, conceive a child in a natural way. Jesus will be born of a virgin' (Card 2011:38)

63. Luke does not say why Elizabeth decided to seclude herself. However, she expresses joy that the disgrace of her barrenness is being removed (Bock 1994:38). Green (1997:81) says that 'Elizabeth's five months of seclusion remain a mystery'. Ambrose believes it was because of modesty (Just 2003:11). Nolland (1989:33) sees he withdrawal from the community as showing 'a sense of privacy about the precious and intimate way that God has dealt with her in her old age'. However, I see Elizabeth's voluntary seclusion as reinforcing the prophetic word to Mary about Mary's own pregnancy. Mary is the only one, besides Zechariah, to know of Elizabeth's pregnancy and Elizabeth is the only one, besides her foetal son and Zechariah, to know of Mary's pregnancy.

64.Elizabeth did not withdraw in order to hide her pregnancy, Geldenhuys (1979:69) believes, but to glorify God and worship him for the miracle she was experiencing (see Lk 1:21-25).

65.John's conception involves a miracle because of the ages of Zechariah and Elizabeth However, it is the result of human intercourse. The conception of Jesus in Mary is a 'divine creative action without human intercourse' (Brown 1988b:252).

66. Elizabeth's miraculous pregnancy was a sign to Mary and serves as a sign to all subsequent believers that Mary's pregnancy impossible as it seems, is not impossible subsequent believers that Mary's pregnancy, impossible as it seems, is not impossible
(Lk 1:36-37; Fitzmyer 1981:321). God often blesses his people with signs and miracles, (Lk 1:36-37; Fitzmyer 1981:321).
thereby increasing their faith.

\section{Mary's Arrival}

[Elizabeth walks back and forth smiling.] One day in my sixth month, I was in my house singing. Zechariah was out shopping for us. I heard my name called by a young woman's voice. ${ }^{67}$ Suddenly things started happening all at once. ${ }^{68}$ Bear that in mind.

I was startled. I turned around and saw my kinswoman, Mary. ${ }^{69}$ Mary is the daughter of Anna, my mother's sister. ${ }^{70}$ Mary is $14 .{ }^{71}$ I knew she was engaged to be married to Joseph, a carpenter in Nazareth. ${ }^{72}$

She called my name. ${ }^{73}$ As soon as she did, the baby in my womb started leaping! What a commotion! I was being violently kicked! Yet they were happy kicks! [Elizabeth chuckles.] Then I felt something entirely new: the Lord came upon me; I was filled with the Holy Spirit. ${ }^{74}$ Then in a very loud voice that surprised me, ${ }^{75}$ I turned to Mary and said, 'Blessed are you amongst women, and blessed is the child you will bear! !76 $^{76}$

67.Wansbrough (2007:22) sees Mary's visit to Elizabeth as an expression Mary's kindness to her ageing relative and as an expression of support to her during the exciting and worrisome time of her pregnancy. However, I believe Kershner (2007:20) is more accurate by saying that Mary came immediately to her cousin Elizabeth's house 'because she did not know where else to go'.

68.Nolland (1989:67) also sees the 'everything happening all at once' sequence. The child's movements and Elizabeth's prophetic words bump into and overlap each other amidst much rejoicing.

69.Luke 1:39-40 addresses Mary's visit this way: 'At that time Mary got ready and hurried to a town in the hill country of Judea where she greeted Elizabeth.' Swanson (2007:101) thinks that Mary, who he calls Mariam, 'ran, perhaps in flight.' He senses urgency in her coming to Elizabeth, an urgency that perhaps indicates she was fleeing for her life.

70.Tradition surrounds the kinship link between Elizabeth and Mary (Holy Apostles Convent 1989:120). Elizabeth, by tradition, is the daughter of Anna's sister, Zoia. Joakim and Anna, by tradition parents of Mary, waited 50 years for Mary's birth. Consequently, if this tradition is correct, Mary follows the line of special children and long-awaited deliverers of Israel: Isaac (Gen 21), Joseph (Gen 37), Moses (Ex 1-2), Samson (Jud 13), Samuel (Sam 1-2) as well as Judith and Esther in the books bearing their names.

71.This drama does not mention the legends about Mary, including her delayed birth, her holiness, her childhood and her participation with other virgins in making the veil of the Temple. However, for a fascinating account of them read The Life of the Virgin Mary, the Theotokos (Holy Apostles Convent 1989, especially pp. 1-73).

72.The normal age for the betrothal of a girl was soon after her twelfth birthday. For boys, the betrothal age was about 16 (Wansbrough 2007:20). The normal engagement time was about a year.

73.The mother of the Lord greeted the mother of his prophet (Holy Apostles Convent 1989:122-123). See Luke 1:40-41.

74.Origen, writing on the significance of Elizabeth's prophecy, notes that 'Elizabeth prophesies before John. Before the birth of the Lord and Savior, Mary prophesies. Sin began from the woman and then spread to the man. In the same way, salvation had its first beginnings from women' (Just 2003:24).

75.Bede notes that Elizabeth had 'a great voice because she recognized the great gifts of God'. She rejoiced and 'was on fire' because of the visit of the Son of God (in the womb) to her (Just 2003:21, 22).

76.Elizabeth blessed Mary by reinforcing what the angel had already said. Elizabeth blessed Mary and blessed the child she was carrying and would bear (Lk 1:42; see Holy Apostles Convent 1989:121). Wansbrough (2007:21) sees God's choice of Mary as 'the unmerited favour of an all-powerful ruler, who needs to justify his deeds to no one; he simply chooses his favourites unpredictably and showers his gifts upon them as he will. Primarily it is the personal relationship, the choice and the love, and only secondarily the gifts, the graces which follow. So God simply fixed his choice upon Mary, quite arbitrarily, not for any merits of hers.' Martin (1982:396) offers an interesting clarification about Elizabeth's words. He points to Jesus' words to woman who blesses the womb that bore him and the breasts he suckled. He replies, 'Blessed are those rather who hear the word of God and keep it' (Lk 1:27-28). Yes, Mary is blessed, because she is pregnant with the son of God, but also because Mary is blessed, because she is pregnant with the son of God, but also because she hears the word of God and keeps it. Fitzmyer (1981:358) notes that Elizabeth gives a blessing and a beatitude over her young kinswoman. Firstly, Mary is blessed (eulogeme) amongst women because of whom she carries in her womb. Secondly, she is blessed (makaria) because of her faith. Wilson (2006:436-456) links three women the biblical text calls blessed: Jael (Jud 5:24), Judith (Jud 13:18) and Mary (Lk 1:42). Whilst the first two were blessed, because they acted as deliverers and saved Israelite lives, Mary, linking verses 42 and 48 , believes she is blessed, because God has looked favourably on the lowliness of his servant (see Wilson 2006:448). Unlike Jael and Judith, Mary is called blessed not for any act of violence but for ' 'Un me according to your word "(Lk 1:38), Wilson (2006:449). Unlike Jael and Judith exemplary women warriors, 'Mary is presented as a woman disciple, a peaceful heare and doer of God's word' Wilson (ibid:449) 
We looked at each other. I was amazed at what I had said, for I had no idea she was pregnant! ${ }^{17}$ My baby was kicking energetically! Mary's mouth opened. My mouth opened. We reached for each other's hands. I continued to shout. ${ }^{78}$

'But why am I so favoured that the mother of my Lord should come to me? As soon as the sound of your greeting reached my ears, the baby in my womb leaped for joy!'

[Elizabeth acts out this encounter, too. She exudes joy, wonder, and laughter.] We looked at each other in astonishment. It was really a meeting of four - our two babies and we two women. ${ }^{79}$ We hugged. We kissed. We shouted. We danced. We patted each other's stomachs. We hugged and kissed again. ${ }^{80}$ We praised the Lord. ${ }^{81}$ But the prophetic word was not over.

[Elizabeth kneels suddenly.] I dropped her hands and knelt before her. I, the older, the woman of the house, knelt before a young woman and my guest. ${ }^{82}$ Even though all that is against our culture, I would do it again and again..$^{83}$

I looked up at her sweet face and said this prophetic word: 'Blessed is she who has believed that what the Lord has said to her will be accomplished!'84

Mary nodded. Mary understood. Mary reached out her hand and helped me up. [Elizabeth rises.] Mary said later that I greatly encouraged her, ${ }^{85}$ for I gave a prophetic word, a spontaneous witness to what had happened to her. ${ }^{86}$

77.Elizabeth speaks as a prophet (Dean 1983:23).

78.One view about Elizabeth's loudness and outbursts is that they teach humanity to cry out to Mary (Holy Apostles Convent 1989:122). However, I see her loudness and words as the energising and power of the Holy Spirit. Furthermore, Elizabeth acknowledges that her words are not from herself but from the Holy Spirit. Therefore, she believes Mary because of what the Holy Spirit did in and through her: Mary's words and rendition of her story simply fill in the details. Similarly, an angel encounters a doubting Joseph in a dream. This divine encounter verifies Mary's words and gives Joseph the clear moral leeway to continue the marriage proceedings and to marry his betrothed (Matt 1:18-25).

79.The meeting of the four - the two mothers and their two sons - produces 'a new tradition of a super-hero's birth' (Brenner 1986:269). Landry (1995:78-79) uses an interesting verb, congratulates, as he sums up the meeting between the kinswomen. Elizabeth's speech 'congratulates Mary for believing that there would be a fulfilment of what was spoken to her from the Lord'. The scene certainly carries tones of exuberance, celebration, joy, anticipation, loudness and singing!

80.Themes common in an account of a super-hero's birth, Brenner (1986:269) continues, are the barrenness of one mother and the unmarried social status of the other Significantly, there is a lack of rivalry - on issues like status, beauty, ambition and age - between them. Instead, the women are mutually supportive and share the commonality of faith. Brenner (ibid:270) points out that the goodwill of the mothers, Mary and Elizabeth, sets the tone for the relationship between their sons by eliminating the possibility of power struggles between them in the future and promoting, instead, good will.

81.Praise acknowledges God's goodness, God's actions and brings attention to God (Bock 1994:45).

82.Elizabeth could have felt resentful and Mary could have shown pride. However neither emotion marks the relationship of these two women. Instead, they celebrate God (see Wright 2004:16)

83.Elizabeth willingly takes the second place. She acknowledges that her young kinswoman has received from the Lord more honour than she has (Geldenhuys 1979:83). Elizabeth's action is part of a similar tradition in scripture: Jonathan knows David will be king (1 Sam 20) and Barnabas lets Paul take the lead midway through the first missionary journey (Ac 13) (Branch 2007:313-319).

84.See Luke 1:45. Mary accepts the miraculous blending of the divine and the human (Dean 1983:23). Mary is blessed and unique because of her faith and the child she carries (see Bock 1994:43-44). 'Blessed is she who has believed' gives the essence of a proper response to God: trust that what God says is true and live joyfully in light of that truth (see Bock 1994:44).

85.See Holy Apostles Convent 1989:122.

86. As a pregnant older woman, Elizabeth is a sign for Mary of faith and miracles. God's work in Elizabeth's life shows that God is at work in Mary's life too (see Martin 1982:397)

\section{Mary's visit for almost three months}

Now I'll tell you about Mary's visit. ${ }^{87} \mathrm{Oh}$, what a joyful time it was! She stayed with us almost three months. ${ }^{88} \mathrm{I}$ believe we gave to her and she gave us so much as well. First, we believed her. We believe she carries the Son of God in her womb. Second, we gave her space to be, to ponder, to consider what to do, to praise God. Third, she could be herself around us. We gave her sanctuary. ${ }^{89}$

Zechariah encouraged her greatly. He unrolled the scroll of Isaiah. He pointed to some words, indicating they were for Mary. Mary and I leaned down to read them. 'Behold, the virgin will be with child and will give birth to a son, and will call him Immanuel. ${ }^{\prime 90}$ Mary is that virgin..$^{91}$

[Elizabeth's smile is tender and that of an older woman who knows life.] I would watch her as she sat at the window, the light gently on her face. Mary is hard to describe. She is small. You would not notice her in a crowd.${ }^{92}$ Yet when you look into her eyes, there is peace. ${ }^{93} \mathrm{I}^{\prime}$ ve never seen eyes like hers. Her eyes tell what is in her soul: peace. It makes her beautiful beyond description.

Mary has two other strong characteristics that I observed. First, she sings. ${ }^{94}$ Mary composed a song while here. ${ }^{95}$ Here are some of its words: 'My soul magnifies the Lord, and my spirit has rejoiced in God my Saviour. For He has regarded the lowly estate of His maidservant. ${ }^{96}$ For behold, from henceforth, all generations will call me blessed. For He who is mighty has done great things for me, and holy is His name. ${ }^{\prime 97}$

87.Acting on the hint that Gabriel gave, Mary comes to her kinswoman, Elizabeth. It was natural to want to be around someone who also was experiencing a miracle (Geldenhuys 1979:82).

88.Nolland (1989:77) observes that the 'three months of Mary's stay may allude to the three months in 2 Samuel 6:11 of the ark's remaining in the house of Obed-edom'.

89.Mary may well have needed sanctuary. According to Swanson (2007:104), 'When Mariam was in danger and overwhelmed and needed someone to take her in, feed her, and tell her stories that would protect and stabilise her in the coming months and years, she went to Elisheva, her auntie.'

90.See Isaiah 7:14 and Matthew 1:23.

91.Drane (2011:55-57) discusses the difficulties modern readers have with the concept of a virgin birth. 'To be a virgin and pregnant is a contradiction in terms,' he (2011:55),
begins and that concept was 'quite unacceptable in any form to orthodox Jews' (Drane ibid:57). Matthew seems to draw from the LXX version of Isaiah, which translates 7:14 as virgin whilst in the Hebrew text the term may refer to a translates 7:14 as virgin whilst in the Hebrew text the term may refer to a young woman (Drane ibid:56-57). Both Luke and Matthew present the materia about Jesus " birth in the same way that they present other material about Jesus: straightforwardly and without elaboration. In terms of textual structure, Mary's virginity parallels Elizabeth's barrenness: neither is an obstacle to God in terms of a promised child (see Nolland 1989:49).

92.Mary remains both fascinating and mystifying throughout the ages. Although the biblical text shows her humility and contentment with lowly things, the Lord called her to greatness and exalted her (Holy Apostles Convent 1989:128).

93.Mary is widely considered the first and model disciple because of her obedience (Wansbrough 2007:27)

94.It's interesting to note that Elizabeth may have spoken what has come to be known as the Magnificat of Mary (Lk 1:46-55)! Whilst Mary is the designated speaker in all Greek manuscripts, Elizabeth is the speaker in three copies of the Old Latin (Vetus Latina) versions. Significantly, Irenaeus credits her as the speaker (Fitzmyer 1981:365). Mary's song resembles that of Hannah (1 Sam 2:1-100). Mary, Hannah and Elizabeth are all women, mothers-to-be, whom God uses in his ongoing actions of salvation. However, Morris (1988:83) says that 'the textual evidence in support of salvation. However, Morris (1988:83) says that 'the textual evidence in support
of Mary is overwhelming' (Morris' italics). The theme of God's faithful love runs of Mary is overwhelming' (Morris' italics). The theme of God's fath
through both Mary's song and Zechariah's (Wansbrough 2007:25).

95. Her hymn emphasises God's present movements. God is acting now and has pledged himself to act forever on Israel's behalf (see Kuist 1948:291 and Lk 1:46-55).

96.0'Day (1985:207) points out that Mary's mention of low estate does not really mean Mary's humility but Mary's poverty.

97.See Luke 1:46-49. Mary links what is happening to her with the history of God's workings with Israel when she sings, 'the Mighty One has done great things for me'
(O'Day 1985:208). 
Mary gave my husband a gift that helped him. She told us her story..$^{98}$ She told us how Gabriel came to her. ${ }^{99}$ Gabriel told her she had found favour with God. ${ }^{100}$ She would be with child and give birth to a son and was to give him the name Jesus. He would be great and would be called the Son of the Most High. ${ }^{101}$

Like Zechariah, she paused to consider these words. She asked a technical question. She asked how his words would come to pass, because she is a virgin. ${ }^{102}$

Gabriel told her that the Holy Spirit would come upon her and the power of the Most High would overshadow her. ${ }^{103}$

Mary accepted what the angel told her. ${ }^{104}$ She said, 'Behold, I am the Lord's servant. May it be to me as you have said. ${ }^{\prime 105}$ As Mary told us her story, emotions of fear, wonder, joy, and perplexity crossed her face. ${ }^{106}$ When she finished, I was thrilled. I reached for her hand. I immediately started talking

98. One tradition is that the annunciation occurred when Joseph was absent from his home and working his trade as a builder (Holy Apostles Convent 1989:71).

99.Significantly, Gabriel came with an announcement of what God was going to do. It was not a command (Geldenhuys 1979:77). See Luke 1:26-38. Notice that Mary was not looking for God, but the angel Gabriel was sent to her.

100. Roman Catholics generally interpret the phrase, 'full of favour,' to mean she can confer favour. Protestants, on the other hand, see the phrase as meaning she has received favour (Geldenhuys 1979:75).

101.The greatness of this Son is unequalled: his greatness will excel everything. In Greek, the phrase is 'Son of the Highest'. It contains no articles, a grammar technique the phrase is 'Son of the Highest'. It contains no articles, a grammar technique
that indicates 'the absolute uniqueness and highness of His divine Sonship' that indicates 'the absol
(Geldenhuys 1979:76).

102. Ryken (2009:34) writes that 'Mary did not ask this question in unbelief. Here Luke is drawing a contrast between Zechariah's doubt and Mary's faith'. In Luke 1:34, one may see that Mary knows that she cannot have intercourse until Joseph takes her home and normal sexual relations as husband and wife begin. Landry (1995:69) translates Mary's words as, 'How will this be, since I do not have sexual relations with my husband?' Landry (1995:69) says that 'Luke has Mary ask the question for no discernible reason other than to give the angel the further opportunity to speak of the child's identity'. However, Smith (1975:417) sees Mary's question, 'How can this be?' as our question, too, especially when we think about Jesus and the promise to mankind that Jesus' story presents. However, Schaberg (1987) argues that Luke to mankind that Jesus story presents. However, Schaberg (1987) argues that Luke generally accepted. One who differs with it is Landry (1995).

103.The concept of theotokos (literally God-bearer) is not to give glory to the mothe but to verify that the life of Jesus - from the very beginning - was God's action.

104. Mary realises that 'she would bear a child without the intervention of a man, perhaps even that conception would be immediate' (Morris 1988:81). By her consent, 'Mary is here a pattern for the Christian faith but also much more: she responds to a call that is unique in human history' (Nolland 1989:59). Mary realised, through her acceptance, that she was chosen for a great task. Barclay (1956:8 provides telling comments: 'The piercing truth is that God does not choose a person for ease and comfort and selfish joy but for a great task that will take all that head and heart and hand can bring to it. God chooses that person to use that person. When Joan of Arc knew that her time was short she prayed, "I shall only last a year use me as you can"' (Barclay's italics). However, Steuernagel (2003:104) gets basic when he says that if you want to understand theology, follow Mary and offer your womb! Such an offer entails many sighs. Steuernagel (2003:104) envisions Mary sighing as she considers the craziness of her offer and its cost to her reputation and later when she grapples with Joseph's confusion (Matt 1:18-19).

105.Wright (2004:12) notes that Mary, when asked to be the mother of the Messiah and although not yet aware of what this involves, 'says the words which have rung down the years as a model of the human response to God's unexpected vocation: "Here I am the Lord's servant-girl; let it be as you have said"." Mary's response "Here I am, the Lord's servant-girl; let it be as you have said". Mary's response echoes the readiness of Abigail (1 Sam 25:41), Sarah (Gen 21:1) and Hannah (1
Sam 1:11) - see Nolland 1989:57. Mary's statement shows that she shows faith Sam 1:11) - see Nolland 1989:57. Mary's statement shows that she shows faith immediately in three ways: she believes the angel's words, willingly lets God use
her, and hurries to visit another, Elizabeth, whom God is also using amazingly (see her, and hurries to visit another, Elizabeth, whom God is also using amazingly (see Bock 1994:44 and Luke 1:38). Ambrose sees it as Mary did not deny the faith, she did not refuse the duty, but she conformed her will, she promised obedience' (Just 2003:17). Irenaeus contrasts Eve and Mary. He writes that 'the former was that the Virgin Mary might become the advocate of Eve' (Just 2003:19).

106.Daniel (2005:26-28) emphasises Mary's perplexity. Calling Luke 1:26-38 a 'news flash,' she (Daniel ibid:26) writes 'that the most important woman in the world, the one who is about to give birth to the son of God, the one who will have to tell her beloved news of a pregnancy that will bring scandal to their new life, the one who will sit at the foot of the cross heroically suffering her son into eternity, the one who now as a young girl will have to have the strength to travel long distances in miles now as a young girl will have to have the strength to travel long distances in miles and even greater distances in faith, begins her adventure in a state of $p$
From the moment the angel greets her, she is confused' (Daniel's italics).
- but was interrupted by Zechariah's sobs. Amazed, Mary and I looked at Zechariah.

Zechariah was weeping great wrenching sobs. His keening came from his innermost being. It was if a boil had been lanced. Mary and I held hands as he wept. We bowed our heads and prayed.

In our presence, Zechariah knelt and repented before God for his unbelief. ${ }^{107}$ Because he couldn't speak, we do not know what he said. He bared his heart to the Lord. He wrote me this later. Mary's story broke him, for he saw before him this small young woman who believed. ${ }^{108}$ And he had not believed what Gabriel said.

[Elizabeth pauses and smiles in tenderness.] But ever since that moment of repentance, Zechariah has been a changed man. He is kinder to me. His sense of humour returned. He enjoys my company. He listens to me. He sees me with eyes of love and understanding. Oh, I hug him all the time and pat his boney shoulder as I go about my tasks. Together we praise the Lord.

Mary left two weeks ago with a group to walk back to Nazareth. I've mentioned Mary's peace and singing ability. Now I'll tell you about her courage. Mary's courage significantly marks her. ${ }^{109}$ She must tell Joseph she is pregnant. Mary's courage amazes me. ${ }^{110}$ Zechariah and I pray daily for their meeting to go well. As a betrothed woman, she is treated the same as is a married woman. ${ }^{111}$ Her pregnancy puts her in great danger, for according to our law, she could be stoned, strangled, or burned to death. ${ }^{112}$ Joseph is not the father of the child she carries. ${ }^{113} \mathrm{We}$ pray that Joseph, too, believes her and marries her quickly. ${ }^{114}$

107. In contrast to Zechariah, who does not initially believe, Luke presents Mary as a model of someone who, in her own particular life, fully and responsibly accepts the will of God (Brown 1988b:259).

108. Ryken (2009:38) offers these telling comments: 'How rare it is to find someone who is willing to trust God for the impossible and then obey him without hesitation or qualification.'

109.What I call Mary's courage, Ryken (2009:39) sees as her faith. Ryken (ibid:39) writes that Mary 'trusted God for all of it - her relationship with Joseph, her reputation in town, her physical suffering, and the anguish of her soul. Mary believed in God and town, her physical suffering, and the an him with trusting obedience.'

110.All people should be amazed at God's plan, as seen in the lives of Mary, Elizabeth, and Zechariah (see Bock 1994:43).

111.The betrothal meant that the couple was treated as married. However, there had not been a consummation. Consequently, matters of inheritance, death, adultery and divorce were handled according to the law. Only divorce could dissolve the betrothal, as with a marriage (Holy Apostles Convent 1989:69; see also Epstein 1939 m. Ketub. 1:2, 4:2; Hagner 1993:17) and Matthew 1:18-25.

112.Swanson $(2007: 102,105)$ points to the penalties in the Talmud for pregnancies outside of marriage. Granted, we do not know if these penalties were in force in Mary/Mariam's time. However, they are sobering. Tractate Kethuboth $44 \mathrm{~b}-45 \mathrm{a}$ says that, if a girl plays the harlot in her father's house, she is to be stoned at the entrance that, if a girl plays the harlot in her father's house, she is to be stoned at the entrance
of her father's house. If witnesses testify she has played the harlot in his house, she of her father's house. If witnesses testify she has played the harlot in his house, she
is to be stoned at the entrance of the gate of the city. If Mary or Mariam has priestly is to be stoned at the entrance of the gate of the city. If Mary or Mariam has priestly
blood, as may be the case, because Elizabeth is a daughter of Aaron, then she could blood, as may be the case, because Elizabeth is a daughter of Aaron, then she could be burned. The Talmudic Tractate Sanhedrin 9:1 states that if the daughter of a
priest plays the harlot, she deserves the capital punishment of burning. Swanson priest plays the harlot, she deserves the capital punishment of burning. Swanson
(2007:103) writes that her name, Mariam, means sea of bitterness. The biblical reference for death by stoning is Deuteronomy 22:20-24.

113.Luke and Matthew report that 'Jesus did not have a father in the ordinary way, and that this was because Mary had been given special grace to be the mother of God's incarnate self' (Wright 2004:10).

114.For the law on adultery and other marriage issues, see Deuteronomy 22:13-30. Bailey (2008:44-46) notices Joseph's anger when he learns of Mary's pregnancy (Matt 1:18-19). Bailey (ibid:46) asserts that a better translation of 'he considered' is 'while he fumed over this matter' (Matt 1:20; Bailey's italics). However, a significant attribute of this just man was that he was able 'to reprocess his anger into grace' (Bailey 2008:47). This drama does not agree with the view that Mary retained her virginity after her marriage to Joseph. However, for a fine summary of those who virginity after her marriage to Joseph. However, for a fine summary of those who
hold this view, see Holy Apostles Convent 1989:74-118 - 'The Annunciation of the hold this view, see Holy Apostles Convent
Mother of God and Ever-Virgin Mary'. 
After Mary left, ${ }^{115}$ Zechariah and I began to sit outside in the evening and watch the stars over Judea. I liked the cold stones on my back. I liked to sit, for the last days of my pregnancy were quite uncomfortable. Zechariah would hold my hand and pat it kindly. I talked of our son, how great he would be. I am sure he will be like the first prophet, Abraham, or maybe like the greatest prophet, Moses. ${ }^{116}$ Zechariah smiles a little sadly at me as I go on and on, as if he knows something I do not. [Elizabeth shakes her head and is a bit sad but then recovers and smiles.] But still, our joy is great and even bursting at this time. We truly have been surprised by joy! We have a baby at our ages! Imagine that!117 We are smitten parents astonished and full of joy!

\section{The circumcision}

[Elizabeth the homemaker and happy mother bustles about her small house.] Now let me tell you about what happened this morning. My son was born eight days ago. Mine was a difficult pregnancy. I was sick. The birth was difficult. I am 68 years old! Miracles may happen, but they take place in human beings!

Yet I knew I would live and that my son would be a viable child. I had the prophetic word. According to the custom of our people, Our son was to be circumcised today, named, and dedicated to the Lord. All our neighbours and relatives were with us, for they knew that the Lord had shown great mercy to me. ${ }^{118}$ Zechariah gave me this shawl as a special gift. [She brings the shawl tenderly to her face again.]

When it came time to name the child, everyone thought the child would be named Zechariah for his father. I said, 'No! He is to be called John. ${ }^{\prime 19}$ There was a big fuss, for we have no relatives of that name. ${ }^{120}$

[Elizabeth, predictably by now, gets louder and louder and happier and happier as she remembers what happened this morning.] A writing tablet was brought for Zechariah. He wrote, 'His name is John.'121 Immediately his tongue was loosed and

115. Mary returned home (Lk 1:56). However, Luke gives no indication of whether that meant her parents' home or the home of Joseph (see Fitzmyer 1981:369).

116.Abraham was the first prophet in scripture (Gen 20:7). Moses, who delivered the Hebrew slaves from Egypt and led them for 40 years in the wilderness, is acknowledged as Israel's greatest prophet. Herod beheaded John (Matt 14:1-12, Mk 6:14-29 and Lk 7:24-35).

117.One of the most beautiful aspects of the infancy narratives is that God deals on micro and macro levels. Whilst preparing to deal with $\sin$, as he promised, through the birth of his son, Jesus, God honours an honourable, obedient and faithful couple the birth of his son, Jesus, God honours an honourable, obedient and faithful couple
by granting them their hearts' desire: a son named John. Wright (2004:8) correctly states that God 'takes care of smaller human concerns as well'.

118. Barclay (1956:11) recounts that, in Palestine at the time, musicians and friends gathered at a house for a birth. If the child was a boy, great celebration followed. If it was a girl, the musicians went away silently and in sorrow. 'So in Elizabeth's house, there was double joy,' Barclay (1956:11) says, because their neighbour had a child at last and that child was a son! See Luke 1:57-66.

119. Her 'No!' is emphatic (Morris 1988:86).

120.With the birth of John 'God vindicates Elizabeth and, coincidentally, provides a prophet of the coming of the Lord,' Green (1997:107) writes.

121.The name John is a shortened version of Jehohanan and means God is gracious (Barclay 1956:12). he could speak! ${ }^{122}$ He started shouting! ${ }^{123}$ He kissed me. He kissed John. He kissed the rabbi. He kissed all our relatives - even the ones he never liked! I held up the baby. Soon John was being passed around and around. He was almost being tossed back and forth! We shouted and praised God, but Zechariah shouted the loudest. He could speak again! Oh, the amazing joy!124

Then Zechariah started singing! Oh, the dear old coot! He was filled with the Holy Spirit, I could tell because I am, too, and he started prophesying. He praised the Lord, the God of Israel for redeeming his people and raising up a horn of salvation for us. ${ }^{125}$ He praised God for rescuing us from the hand of our enemies ${ }^{126}$ and enabling us to serve him with righteousness and holiness all our days. ${ }^{127}$

Then he tenderly took young John from my arms and cradled him. ${ }^{128}$ He spoke to the baby in this way:

'And you, my child, will be called a prophet of the Most High. ${ }^{129}$ You will go on before the Lord to prepare the way for him. You will give his people the knowledge of salvation through the forgiveness of their sins. ${ }^{130}$ 'The tender mercy of our God has come upon us. The Dayspring from on high has visited us. ${ }^{131}$ God will give light to those who sit in darkness and the shadow of death. ${ }^{132}$ God will guide our feet into the way of peace. ${ }^{\prime 133}$

122.Perhaps he could now also hear, because the text hints that Zechariah was also deaf (Lk 1:20, 62; Branch 2009:35). The miracle of Zechariah's sudden speech attests to the specialness of the child. He, like Elizabeth, filled with the Spirit, becomes 'the mouthpiece of God' (Fitzmyer 1981:382)

123.Maximus of Turin sees the timing of the baby's being named John and Zechariah's sudden ability to speak again as miraculous and symbolic, because the child 'gave his father back his voice, he restored the faculty of speech to the priest ... John unloosed the mouth that the angel had bound. What Gabriel had closed the little child unlocked ... When John is born the father suddenly becomes a prophet or priest, speech attains its use, love receives an offspring, the office recognizes the priest' (Just 2003:29).

124.The events leading up to John's circumcision and what took place at the circumcision show that God is moving again amongst his people and in Israel's history (see Fitzmyer 1981:309).

125.The horn of salvation (Lk 1:69) expresses joy and might, strength as well as power. All are attributes of the God of Israel. Here, designating an agent of God's salvific power in David's line, it becomes 'in a loose sense a messianic title' (Fitzmyer power in David's line, it becor
1981:383; See Lk 1:67-79).

126.Consider this logic: because God saved Zechariah from his unbelief, he surely can save Israel from her enemies (see Branch 2009:37).

127.Zechariah's prophetic song breaks neatly into two parts. Verses $68-75$ offer praise to the God of Israel. Verses 76-79 give a broad job description for his son, John (Branch 2009:33).

128.Wright (2004:18) believes that the song shows Zechariah as one 'who has pondered the agony and the hope for many years, and who now finds the two bubbling out of him as he looks in awe and delight at his baby son'. Morris (1988:89) observes that 'we might have expected that Zechariah's song would be all about his little boy. He surprised us by beginning with the Messiah whom God was about to send.'

129.Zechariah and Elizabeth both realise that their son's role was not the main one in the drama. Granted, he was to be honoured as 'the prophet of the Most High,' but he was not the 'Son of the Most High' (Lk 1:76, 32; Dean 1983:25). John will be like the servant in Isaiah 49:5 - and a servant with a daunting task: that of restoring Israel to God (Nolland 1989:35-36).

130.See Luke 1:76-77. Elizabeth and Zechariah's son John will proclaim God's salvation and Mary's baby will be the salvation (Bock 1994:5). Zechariah's prophetic words emphasise restoration. Barclay (1956:13-14) rightly emphasises the key aspect of forgiveness. It does entail looking again at the penalty. More importantly, it aims to restore a relationship (Branch's italics). Significantly, this restoration begins at
the instigation of the one wronged: God.

131.Kuist (1948:298) expresses it as: 'Because of God's heart of mercy, 'the day-spring from on high' was at hand.'

132.Ryken (2009:64) sees the condition of Israel before the birth of Christ as dark days and that darkness 'is the situation we are all in until we are saved'.

133.Card (2011:44) writes that Zechariah sings 'a song about a new world where the condition in which one will serve God is love and faithfulness and joy'. In the old world order, the predominant emotion in the service of God was fear (Card 2011:44). 
Well, after that, we hugged and kissed some more. Our guests and neighbours were filled with awe. ${ }^{134}$ John got cranky, so I took him and fed him and put him down to sleep. Oh, how I pray that joy will mark my son's life as it has done so far. ${ }^{135}$ [Elizabeth rests her cheek on her shawl.]

\section{Conclusion}

[Elizabeth pauses and paces.] Well, what would I like you to remember and know? What I have spoken to you is true. ${ }^{136}$ Mary, of course, was the first to know that Jesus, the son she carries, is the Son of God. But I, Elizabeth, I and the baby son within me were the second to recognise that the Son of God is in the womb of Mary. ${ }^{137}$ There will be others, many others who will know Jesus as the Son of God. ${ }^{138}$ I hope you are one of them. ${ }^{139}$ But while I knelt before Mary delivering the prophetic word to her, I listened as well. The pronouns were she and her. 'Blessed is she who has believed that what the Lord has said to her will be accomplished.'

At times the prophetic word is deliberately vague and ambiguous; the word man can include woman as well. ${ }^{140} \mathrm{At}$ times the prophetic word is like ripples in a pond and can apply again and again. The pronouns she and her obviously applied to Mary. I thought later that they could apply to me as well. ${ }^{141}$ I have believed the Lord; I, too, have received his favour. ${ }^{142}$ What he has said to me has been accomplished. And so I tell you as well, take this word, be you woman or man. It is God's living word.

[Elizabeth puts out her right hand toward women in the audience.] 'Blessed is she who has believed that what the Lord has said to her will be accomplished.'

134.Nolland (1989:81) prefers the word fear to awe because 'a totally unlikely pregnancy, a strange insistence on a completely unexpected name, and the subsequent instantaneous recovery of Zechariah combine to produce that involuntary response of fear of the divine activity which Luke is so fond of noting' (cf. 5:26, 7:16, 8:37, etc.).

135.See Bock 1994:43.

136. In a very real sense, this monologue incorporates worship, because it explains the biblical text. Long (2001:43) defines worship as a service allows 'the drama already present in worship to be brought to the surface and to be more deeply experienced" (Long's italics).

137.See Holy Apostles Convent 1989:123. Doriani, Ryken and Phillips (2008:69) are incorrect when they write that John was the first to recognise Jesus as the Christ. Furthermore, they ignore the contributions of Elizabeth entirely.

138.Darden (2006:13) seems to note the joy of those throughout the ages who wish to communicate the good news to others when he writes, 'Here's the wonderful thing - we are part of that story! We play an important role in God's Great Plan. this is our story! The Bible is our roadmap and our cast list. Knowing how these This is our story! The Bible is our roadmap and our cast list. Knowing how these will know our parts in this great cosmic comedy or drama.'

139.I designed this monologue to be fun, but academic in the sense of solid research. It is not devotional, although both men and women have wept during the many times I have presented it. I designed it to encourage a deeper awareness of formative events in the lives of Elizabeth, Zechariah and Mary in the ongoing, wonderfu work of God in history (cf. Ratcliff 1992:129-130). The monologue and Luke 1 emphasise the prominence of the upcoming Davidic king and acknowledge the importance of 'his prophetic precursor, John' (Nolland 1989:24).

140.See Psalm 1, for example.

141.Whilst characteristics like 'blameless' and 'upright' describe Zechariah and Elizabeth the designation of virgin describes Mary. Mary becomes the first model disciple in the nilling to tak willing to take God at his word, willing to experience the unknown and willing to believe past her natural understanding. She is even a good songwriter! Likewise (Bock 1994:43).

142.See Luke 1:25, 43
[Elizabeth puts out her left hand toward men in the audience.] 'Blessed is he who has believed that what the Lord has said to he will be accomplished. ${ }^{143}$

And blessed, blessed, blessed be the Holy One of Israel! [Her hands are raised in joy and praise.]

[Her face melts in happiness. She cocks her head stage left.] Ah, do you hear what I hear? I hear John. He's awake and fussy. I must go nurse the little prophet. Please excuse me. Please come again. ${ }^{144}$ [Elizabeth bobs a curtsy, adjusts her shawl, and exits stage left.]

\section{Acknowledgements Competing interests}

The author declares that she has no financial or personal relationship[s] that may have inappropriately influenced her when she wrote this article.

\section{References}

Bailey, K.E., 2008, Jesus through Middle Eastern Eyes: Cultural Studies in the Gospels, InterVarsity Press, Downers Grove.

Barclay, W., 1956, The Gospel of Luke, The Westminster Press, Philadelphia.

Barragar, P., 1981, Spiritual Growth Through Creative Drama For Children and Youth, Judson Press, Valley Forge.

Bauckham, R., 2002, Gospel Women: Studies of the Named Women in the Gospels, William B. Eerdmans Publishing Company, Grand Rapids.

Bock, D.L., 1994, IVP Commentary Series: Luke, InterVarsity Press, Downers Grove.

Branch, R.G., 2005, 'Teaching the Old Testament Book of Proverbs Via a Play', Christian Higher Education 4(1), 57-69. The Society of Biblical Literature Forum also published it in http://www.sbl-site.org/Article.aspx?Articleld $=488$

Branch, R.G., 2007, 'Barnabas: Early Church Leader and Model of Encouragement', In die Skriflig (41)2, 295-322.

Branch, R.G., 2009, 'Exegetical Perspective: Luke 1:68-79', in D.L. Bartlett \& B.B. Taylor Bartlett and B.B. Taylor (eds.), Preaching the Revised Common Lectionary: Feasting on the Word, Year C, Volume 1, pp. 33-37, Westminster John Knox Press, Louisville.

Branch, R.G., 2010, 'He is Risen! A Play Based on Acts 1:1-12', In die Skriflig 4(1), 229-258.

Brenner, A., 1986, 'Female Social Behaviour: Two Descriptive Patterns within the "Birth of the Hero" Paradigm', Vetus Testamentm 36(3), 257-273. http://dx.doi.org/ 10.1163/156853386X00320

Brown, R.E., 1988a, 'The Annunciation to Zechariah, the Birth of the Baptist, and the Benedictus (Luke 1:5-25, 57-80)' Worship 62(6), 482-496.

Brown, R.E., 1988b, 'The Annunciation to Mary, the Visitation, and the Magnificat (Luke 1:26-56)' Worship 62(3), 249-259.

Card, M., 2011, Luke: The Gospel of Amazement, IVP Books, Downers Grove.

Conrad, E.W., 1985, 'The Annunciation of Birth and the Birth of the Messiah', Catholic Biblical Quarterly 47(4), 656-663.

Daniel, L., 2005, 'Borne in Perplexity: Luke 1:26-38', Journal for Preachers 29(1), 26-28.

Darden, R., 2006, Reluctant Prophets and Clueless Disciples: Introducing the Bible by Telling Its Stories, Abingdon, Nashville.

Dean, R.J., 1983, Layman's Bible Commentary: Luke, Broadman Press, Nashville.

DiYanni, R., 2008, Literature: Approaches to Fiction, Poetry, and Drama, McGraw Hill, Boston.

Doriani, D.M., Ryken, P.G. \& Phillips, R.D., 2008, The Incarnation in the Gospels, P\&R Publishing, Phillipsburg.

Drane, J., 2011, Introducing the New Testament, Fortress Press, Minneapolis.

Edyvean, A.R., 1970, This Dramatic World: Using Contemporary Drama in the Church, Friendship Press, New York.

Ehrensperger, H., 1962, Religious Drama: Ends and Means, Abingdon Press, New York.

143.Elizabeth's monologue has sought to create an experience in which the audience has listened to how God moved in a mighty way in the lives of ordinary people. I hope that the audience can reflect upon her words in fruitful and creative ways (see McNabb \& Mabry 1990:51)

144.According to tradition and the writings of the Church Fathers Epiphanius, Basil and Cyril of Alexandria, Zechariah died a martyr in the Temple between the porch and the altar Herod ordered his death bause he refused to disclose the location and the altar. Herod ordered his death, because he refused to disclose the location
of his son (Thurston \& Attwater 1956:IV-267). We know nothing about Elizabeth's of his son (Thurston \& Attwater 1956:IV-267). We know nothing about Elizabe
death. Their saint's day is November 5 (Thurston \& Attwater 1956:IV-267). 
Epstein, I. (ed.), 1939, Babylonian Talmud, The Soncino Press, London.

Fitzmyer, J., 1981, The Gospel According to Luke I-IX, Doubleday, New York.

Geldenhuys, N., 1979, The New International Commentary on the New Testament: The Gospel of Luke, William B. Eerdmans Publishing Company, Grand Rapids.

Green, J.B., 1997, The Gospel of Luke, William B. Eerdmans Publishing Company, Grand Rapids.

Hagner, D.A., 1993, Word Biblical Commentary, Volume 33A: Matthew 1-13, Word Books Publisher, Dallas.

Hann, R.R., 1986, 'Election, the humanity of Jesus, and possible worlds', Journal of the Evangelical Theological Society 29 (3), 295-305.

Holy Apostles Convent, 1989, The Life of the Virgin Mary, the Theotokos, The Holy Apostles Convent and Dormition Skete, Buena Vista.

Just, A. Jnr, (ed.), 2003, Ancient Christian Commentary on Scripture: Luke, InterVarsity Press, Downers Grove.

Karris, R.J., 1985, 'Luke's soteriology of with-ness', Currents in Theology and Mission 12(6), 346-352.

Kershner, S.J., 2007, Advent Sermon: Luke 1:39-55', Journal for Preachers 31(1), 20-22.

Kuist, H.T., 1948. 'Sources of power in the nativity hymns: An exposition of Luke 1 and 2', Interpretation 2(3), 288-298. http://dx.doi.org/10.1177/002096434800200302

Landry, D.T., 1995, 'Narrative Logic in the Annunciation to Mary (Luke 1:26-38)', Journal of Biblical Literature 114(1), 65-79. http://dx.doi.org/10.2307/3266590

Loader, W., 2007, The New Testament with Imagination: A Fresh Approach to Its Writings and Themes, William B. Eerdmans Publishing Company, Grand Rapids.

Long, T.G., 2001, Beyond the Worship Wars: Building Vital and Faithful Worship, The Alban Institute, N.P.

Lostracco, J. \& Wilkerson, G., 2008, Analyzing Short Stories, Kendall/Hunt Publishing Company, Dubuque.

Martin, J.P., 1982, 'Luke 1:39-47', Interpretation 36(4), 394-399. http://dx.doi.org/ 10.1177/002096438203600408
Marx, S., 2000, Shakespeare and the Bible, Oxford University Press, Oxford.

McNabb, B. \& Mabry, S., 1990, Teaching the Bible Creatively: How to Awaken Your Kids to Scripture, Zondervan, Grand Rapids.

Morris, L., 1988, Luke: An Introduction and Commentary, IVP Academic, Downers Grove.

Murphy, F.J., 2005, An Introduction to Jesus and the Gospels, Abingdon Press, Nashville. Nolland, J., 1989, Luke 1-9:20, Word Biblical Commentary, Word Books Publisher, Dallas.

Ratcliff, D.E., 1992, 'Social Contexts of Children's Ministry', in D.E. Ratcliff (ed.), Handbook of Children's Religious Education, pp. 119-142, Religious Education Press, Birmingham.

Ryken, P.G., 2009, 'Luke: Volume 1, Luke 1-12', P\&R Publishing, Phillipsburg.

O'Day, G.R., 1985, 'Singing Woman's Song: A Hermeneutic of Liberation', Currents in Theology and Mission 12(4), 203-210.

Schaberg, J., 1987, The Illegitimacy of Jesus: A Feminist Theological Interpretation of the Infancy Narratives, Harper \& Row, San Francisco.

Smith, D.M., 1975, 'Exposition of Luke 1:26-38', Interpretation 29(4), 411-417. http:// dx.doi.org/10.1177/002096437502900406

Steuernagel, V.R., 2003, 'Doing Theology with an Eye on Mary', Evangelical Review of Theology 27(2), 100-112.

Stonehouse, C., 1998, Joining Children on the Spiritual Journey: Nurturing a Life of Faith, Baker, Grand Rapids.

Swanson, R.W., 2007, 'Magnificat and crucifixion: The story of Mariam and her son' Currents in Theology and Mission 34 (2), 101-110.

Thurston, H. \& Attwater, D., 1956, Butler's Lives of the Saints, 4 Vols., P. J. Kenedy \& Sons, New York.

Wansbrough, H., 2007, Luke, Daily Bible Commentary: A Guide to Reflection and Prayer, Hendrickson Publishers, Peabody.

Wilson, B.E., 2006, 'Pugnacious Precursors and the Bearer of Peace: Jael, Judith, and Mary in Luke 1:42', Catholic Biblical Quarterly 68, 432-456.

Wright, N.T., 2004, Luke for Everyone, Westminster John Knox Press, Louisville. 